bryst er det mange som tror kan få stor betydning, og denne metoden er beskrevet og illustrert i detalj i et eget kapittel. Alt $i$ alt er dette en godt oppdatert lærebok.

Forfatterne innleder alle kapitlene med en kort oppsummering i form av nøkkelpunkter. Det er mange figurer og illustrasjoner samt fyldige referanselister. De fleste bildene har et veldig gammelmodig, gulnet preg, og det er faktisk min største innvending. Histologiske bilder er derimot av utmerket kvalitet. Noen bilder har ingen verdi som illustrasjon, f.eks. når det gjelder påvisning av vaktpostlymfeknuter. For en som ikke vet hvordan dette ser ut, vil bildet være mer forvirrende enn oppklarende.

Papirkvaliteten er veldig bra med glanset papir. Innbindingen er god og tåler mye bruk.

Ingen av forfatterne er tidligere kjent for meg, men de skriver alle godt om hver sine emner, og det er faktisk nokså lik oppbygging og jevn vektlegging av de ulike temaene. Oppbygningen er pedagogisk god, og teksten er lett å lese. Dette er en nyttig bok som jeg kan anbefale alle leger som skal arbeide med brystkreftpasienter, kanskje spesielt for kirurger. For pasienter er den altfor avansert.

\section{Ellen Schlichting}

Avdeling for bryst- og endokrinkirurgi

Oslo universitetssykehus, Ullevål

\section{Annerledes lærebok i medisinens historie}

\section{Jacalyn Duffin}

\section{History of medicine}

A scandalously short introduction. 2. utg. 495 s, tab, ill. Toronto: University of Toronto Press, 2010. Pris USD 35 ISBN 978-0-8020-9556-5

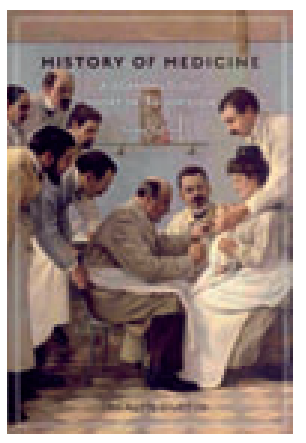

Det finnes mange lærebøker i medisinsk historie, beregnet på legestudenter og andre på vei inn i et helseyrke. Duffins bok skiller seg ut fra de fleste av dem, ikke minst gjennom tilnærmingen til stoffet. Jacalyn Duffin (f. 1950) er lege og spesialist i hematologi. I tillegg er hun historiker av fag og har doktorgraden i vitenskapshistorie og vitenskapsfilosofi fra Sorbonne i Paris. I 1988 ble hun professor i medisinens historie i den såkalte Hannah Chair ved Queen's University i Kingston, Ontario, Canada. Hun har omfattende undervisningserfaring, og i 1999 kom første utgave av læreboken History of medicine: a scandalously short introduction ut, basert på hennes forelesninger. Den ble straks meget populær, trykt opp seks ganger og også oversatt til koreansk, før en ny og revidert utgave nå foreligger i 2010 .

Det er 16 kapitler som til sammen dekker de viktigste feltene innenfor medisinens historie. Hva som skal velges ut til å være med i en lærebok, vil være en vurderingssak, men her har forfatteren åpenbart bestemt seg for å drøfte historiske emner som går ut over seg selv, og som egner seg til å belyse generelle trekk og prosesser.

Man merker hele tiden at Duffin både har legens og historikerens tenkemåte, og at målgruppen er studenter som skal arbeide med aktuelle helseproblemer. Det er riktignok en kronologi i stoffet, slik at f.eks. både de gamle grekerne og Gro Harlem Brundtland er omtalt, men kapitlene er tematiske og etterlater leseren med næring til strukturert refleksjon. Hun hjelper også til med denne refleksjonen ved å angi en liste over læringsmål for hvert kapittel. Det er ikke litteraturlister, men leserne henvises til bokens egen hjemmeside, http://histmed.ca, som er en bibliografisk nøkkel til videre lesning.

Forfatterens mål er å fremme forståelsen av historiens betydning for arbeid med nåtidig medisin og å gi en viss kritisk holdning til den dogmatiske karakteren øvrig undervisning i medisin kan ha. Dette lykkes hun bra med. Den studenten som leser denne boken, vil garantert få aha-opplevelser også $i$ andre fag. Boken er konstruert slik at den kan benyttes både som pensum ved en gammeldags forelesningsserie - hvilket mange mener fortsatt er den beste måten å formidle medisinhistorie på - og ved integrerte studieplaner der medisinens historie blir undervist som små drypp hele veien.

Kapittel 16 om medisinhistorisk forskningsarbeid bør være obligatorisk lesning for studenter som skal skrive spesialoppgave.

Er det noen ankepunkter? Boken er, tross sin spennvidde, nokså knyttet til angloamerikansk medisin. Dette kan imidlertid utnyttes pedagogisk ved at man i undervisningen engasjerer studentene og får dem til å se på temaene i den nasjonale, f.eks. norske, konteksten.

Jeg synes undertittelen er litt rar: A scandalously short introduction. Den stemmer ikke. Som lærebok er den ikke scandalously short, men passe stor, konsis og grei.

\section{Anbefales!}

\section{Øivind Larsen}

Institutt for helse og samfunn

Universitetet i Oslo

\section{Hvordan få flest mulig til å donere organer?}

Jason T. Siegel, Eusebio M. Alvaro Understanding organ donation

Applied behavioral science perspective. 392 s, tab, ill. Chichester: Wiley-Blackwell, 2009. Pris GBP 75

ISBN 978-1-4051-9213-2

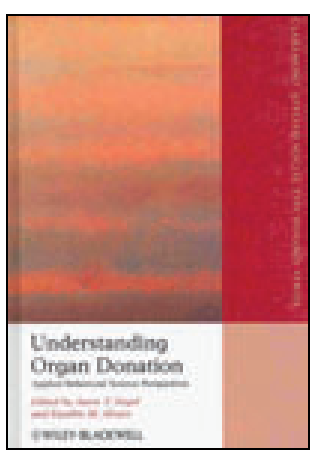

Det er mangel på organer for transplantasjon. Hva er den beste fremgangsmåten for å rekruttere flest mulig til å bli organdonorer? Er det bedre med donorkort enn med sentrale donorregistre? Hvordan skal man klare

å øke donasjonen i minoritetsgrupper, som ofte skiller seg ut kulturelt og sosialt? Dette er hovedspørsmålene i denne boken, hvor målgruppen er forskere og helsepersonell som er involvert $i$ organdonasjon og rekruttering. Boken er basert på presentasjonene ved et årlig symposium i anvendt sosialpsykologi ved Claremont Graduate University i California, USA. Redaktørene og bidragsyterne har mange års erfaring med forskning og rekrutteringsarbeid.

Med unntak av ett kapittel handler boken om organer fra avdøde, og den baserer seg på nordamerikanske forhold. I USA har statene noe ulik lovgiving og praksis, der det varierer hvorvidt donorkort og merkede sertifikater er juridisk bindende. I to innledende kapitler gir man på forskjellig måte en god oversikt over organdonasjon (i USA) og metoder for rekruttering av donorer.

Forfatterne ser i hovedsak på tre typer intervensjoner: gjennom media, mot bestemte samfunnsgrupper og i organisasjoner (helsevesenet og frivillige organisasjoner). Intervensjonene kan være kampanjer, informasjonsspredning, undervisningsopplegg og overtalelsesteknikker, og de bygger på ulike modeller innen anvendt sosialpsykologi og atferdsfag. I tillegg drøfter forfatterne ulike metoder for å måle og vurdere utbytte av intervensjoner for å høyne antallet donorer.

Hva virker? Hvordan får vi flere organdonorer? Man viser at flere tiltak synes effektive, uten at noen peker seg ut spesielt Ulike tiltak kan også sammen gi økt antall organer.

Selv om lovgivingen, helsevesenet og mediesituasjonen er forskjellig i Norge og USA, kan boken gi oss nyttige innspill til hvordan vi i Norge bedre kan bidra til at befolkningen får et mer bevisst forhold til organdonasjon. Det jeg savner mest, er en åpen diskusjon av premissene for intervensjonene og metodene: Er det riktig 